Extrême-Orient Extrême-Occident

\section{Extrême-Orient Extrême-Occident}

$36 \mid 2013$

Mobilité humaine et circulation des savoirs techniques (XVII ${ }^{\mathrm{e}}$-XIX ${ }^{\mathrm{e}}$ siècles)

\title{
Revisiting Social Theory and History of Science in Early Modern South Asia and Colonial India
}

Retour sur la théorie sociale et l'histoire des sciences de l'Asie du Sud de la première modernité et l'Inde coloniale 重估近代早期南亞與殖民地印度的社會理論和科學史

\section{Dhruv Raina}

\section{OpenEdition}

\section{Journals}

\section{Electronic version}

URL: http://journals.openedition.org/extremeorient/315

DOI: 10.4000/extremeorient.315

ISSN: 2108-7105

Publisher

Presses universitaires de Vincennes

\section{Printed version}

Date of publication: 31 December 2013

Number of pages: 191-210

ISBN: 978-2-84292-404-1

ISSN: 0754-5010

\section{Electronic reference}

Dhruv Raina, «Revisiting Social Theory and History of Science in Early Modern South Asia and Colonial India », Extrême-Orient Extrême-Occident [Online], 36 | 2013, Online since 01 June 2017, connection on 19 April 2019. URL : http://journals.openedition.org/extremeorient/315; DOI : 10.4000/ extremeorient.315 


\title{
Revisiting Social Theory and History of Science in Early Modern South Asia and Colonial India
}

\author{
Dhruv Raina
}

The expansion of the history of sciences of the Asian regions has thrown up a number of historiographic challenges and openings for reconceptualising the field, the least of which today has to do with the expansion of the dominion of modern sciences following the voyages of discovery. ${ }^{1}$ As the essays in this volume testify, as do several other volumes, ${ }^{2}$ discussion has ranged between the distinct sciences and technological practices of the Asian region and within the region as much as between so called "modern (Western) science" and the so-called "traditional sciences," though both terms within quotation marks have been extensively problematised.

As Catherine Jami's introductory remarks suggest, the historiographic turn inaugurated by Joseph Needham's Science and Civilisation in China project $^{3}$ played a central role in "catalysing" research in the Asian sciences in the form of a renewal extending from Japan to Turkey and beyond. The widely prevalent frames of civilizations, united by the so-called classical languages and, much later, by culture and nation, dominated that initial phase of renewal and interrogation and provided the medium for the counter-narratives of the history of sciences of the first decades of decolonisation. Over the next three decades, a variety of cognitive and interdisciplinary movements have transformed that academic landscape and created a space for a shift in social theoretic emphasis.

The papers in this volume examine in detail the vocation of "itinerant savants" from East Asia in the transmission of scientific knowledge with very diverse motivations, contexts, and historical periods in mind. These itinerant savants, state officials, and missionaries, to borrow a term from The Brokered World, serve as "go-betweens" engaged in translating knowledge between

1. Basalla 1968; Storey 1996.

2. Bretelle-Establet 2010; Günergun and Raina 2011.

3. Needham et al. 1954- 
two or more distinct worlds and traditions. ${ }^{4}$ These go-betweens were not just information carriers - we have long since abandoned any linear theory of translation-but co-creators of new knowledge, traditions, institutional practices who reworked organizational landscapes for the production of knowledge. In conformity with the spirit of the essays, I restrict my "regard extérieur" to the form of comments in comparative context. Not being a specialist of the Chinese, Japanese, or Korean histories of knowledge, my remarks are to be seen as jottings in the margin of the essays, highlighting what may have happened in a neighbouring Western world before the "West" itself shifted in the social imaginary of East Asia, underlining similarities and differences arising perhaps from similar processes unfolding in time but different contexts. And all along while discussing India or South Asia, the referent is a large geographical expanse that we are habituated to sweep into a civilizational or homogenous entity in a way that runs counter to the spirit of current historiographical trends. These contemporaneous jottings in the margin are inspired by the idea of histories being not only connected but also deeply entangled. ${ }^{5}$

While several interesting themes and historiographic apercus come up for discussion, some important themes could possibly become subjects for future discussions in a comparative perspective. The first has to do with the encounter between distinct or related knowledge systems in South Asia-ilm al hayá or jyotisha for astral sciences, unāni or āyurveda in medicine-separated by physical and political boundaries. In the circulation of knowledge, one form of system differentiation is reflected in centre-periphery relations produced between different knowledge - producing communities. While the framework is possibly appropriate to the study of the forms of legitimation and appropriation of knowledge in Japan or Korea and China, the framework works out differently in the Mughal Empire on the one hand and in what constituted its periphery, and colonial India and the metropolis of modern science in the 19th century on the other. In this last period, as Ian Inkster pointed out, the absence of political sovereignty is played out very differently in the circulation of knowledge when compared with 18th- and 19th-century Japan or China. ${ }^{6}$

This brings us to the related question of strategies of appropriation/ assimilation of new knowledge and the associated strategy of legitimation. In the discussion that follows, in contrast with the case of the Japanese engineer

\footnotetext{
4. Schaffer et al. 2009.

5. Subrahmanyam 1997.

6. Inkster 1988.
} 
Shimomura Kôtarô, ${ }^{7}$ I present the case of "engraftment" in mathematics education, both as an instance of legitimating new knowledge as well as an example of the technology of translation from the European mathematical tradition to the largely composite Indian one. In fact, the study on the Japanese engineer intersects most closely with the issues that surface in my own work. The second issue raised in Aleksandra Kobiljski's paper is a larger question of the use of biographical material in the history of sciences. But, most importantly, each of the studies focuses on more or less itinerant intellectuals or individuals, some of whom were practicing scientists, state officials, travellers, merchants, and missionaries. Often enough, the itinerant's or go-between's creativity and capacity for innovation derive from the transformation into what Veblen would have called a "hyphenate... in the gentle republic of learning," since she or he acquires that sceptical animus, the "Unbefangenheit, release from the dead hand of conventional finality." ${ }^{8}$ At a more systemic level, centre-periphery models have explained how distance from the centre plays itself out in idea hybridizations at the periphery in the absence of peer pressure. ${ }^{9}$

\section{The "knowledgescape" of Early Modern and Precolonial South Asia}

The term "science" is employed as shorthand for the variety of constellations of knowledge dealing with the natural world, though not exclusively. In early modern South Asia, we cannot but encounter the connectedness between knowledge forms and practices from other regions of the world. But in this case, the intent is not so much to reiterate the Needhamian argument of how this connectedness prepared the ground for the rise of modern science itself, but on the contrary seeks to interrogate some of the premises on which the narratives of the modernity of science itself is constructed. In that sense, the newer historiographies seek to abandon overdeterminationist theories of history ${ }^{10}$ while at the same time conceptually pushing research on early

7. See Aleksandra Kobiljski's article in this issue.

8. Veblen 1919: 38-9.

9. Gizycki 1973.

10. Overdeterminationism could be seen as a metahistorical frame providing an explanation for "the apparent irreversibility... of the spread of the Western conception of science" by appealing to the rationality of science as a motive force of history. The idea then is that the so called expansion of Western science is premised on "humanity's natural susceptibility to the scientific world-view." Consequently, the non-West becomes a "voluntary collaborator" in the Western scientific project. See Fuller 1997, p. 87. In 
modern South Asia or East Asia towards a revised social history of knowledge. However, while the papers in this volume observe a deep sensitivity to local context, my remarks for the sake of comparison in the first half will attempt to present a broad "knowledgescape" advent of colonialism and then very briefly substantiate a case of mathematics education during the colonial period in order to contrast the different modalities of "brokering" during the two periods.

The history of knowledge, like the history of sciences in South Asia, during the period of early modernity has for long been framed by a social theory now considered problematic. The scientific renaissance that swept Europe between the 16th and 18th centuries has been paradigmatic for writing these earlier histories of knowledge in South Asia. In these histories, a gigantic institutional and epistemological transformation characterized the world of knowledge in Europe. In contrast, the period in South Asia was more often than not portrayed as either a dark age or one of decline or stagnation, depending upon the historiographical orientation of the scholar concerned. These frames have since undergone a major revision both at the level of the social theory that underpins historiography and in terms of the historical material on which these narratives have been drawn up. While the issue of modernity has been central to discussions of science and knowledge in the modern world, this frame of modernity has structured the discussion of knowledge in South Asia. Colonialism was seen ambivalently as a force that rushed in to reverse the process of decline or stagnation that had set in over the centuries. The accent of postcolonial theory and history, on the other hand, has been to highlight the epistemological violence that colonial education inflicted in the transition from the South Asian epistemic orders to the Western one. ${ }^{12}$

However, a double error frequently marks both sides of the epistemic divide. On the one hand, while the exceptionalism of European modernity is often exaggerated, the newer histories of knowledge have begun to underscore the entangled, connected, and transcultural nature of both modernity and history. On the other hand, the accounts of indigenous knowledge overplay

other words, the accidents of history must be evoked to explain the disruption of the natural pathways of scientific evolution in non-Western societies.

11. The term was introduced by Ulf Matthiesen to underscore the context dependency of spatial developmental pathways of knowledge production processes. Attempting to overcome the "one-size-fits-all" descriptions, it emphasizes spatial dependency of knowledge-based social dynamics. The term could be used as a shorthand for the more current "geographies of knowledge." See Matthiesen 2005.

12. Cohn 1997. 
the nature of the indigenous and its lack of connection with the Western forms of knowledge - in fact, both standard accounts overplay civilizational exceptionalism. Over the last decade, studies on Sanskrit knowledge systems have begun to tell a different story of the world of knowledge in South Asia before colonialism, suggesting important areas of convergence with knowledge in the age of European modernity as well as significant points of departure. ${ }^{13}$ For one, the pre-colonial period is no longer considered a dark age or an age of stagnation characterised by the reproduction of the traditional order with little scope for innovation. This change in perspective occurred in two stages. In the first instance, historical studies from the 1970s disclosed how the 18th century was often portrayed as a century of political instability and declineand then went on to undo this standard picture. ${ }^{14}$ In the decade that followed, as will be suggested, this idea was then extended into the preceding centuries. The new studies seem to suggest, on the other hand, that there was a South Asian modernity; its beginnings are more or less concurrent with European modernity, and it may not be very difficult to argue that these modernities were connected or entangled. ${ }^{15}$ As in most other parts of the world, the region was marked by multiple and overlapping cosmological orders inscribed textually by the major language systems, namely the Sanskritic and the Persianate. In late antiquity, Pali, Prakrit, and Sanskrit were the languages of written communication. However, as we move into early modernity, besides the major languages of Sanskrit and Persian, a variety of vernacular languages ascend to the status of languages of literary communication, learning, and instruction.

In like manner, the world of learning in early modern South Asia presents not just a new intellectual order but also the proliferation of new literary genres and conceptual engagements with the past and what was considered to be the grand tradition. We are informed that the region was marked by the presence of at least three distinct scholarly communities. ${ }^{16}$ There were the cosmopolitan intellectuals who wrote in Sanskrit, which had been the language of scholarship in the sciences and social sciences for centuries just as Latin was in Europe. Similarly, there were intellectuals who wrote in Persian. Till recently, it was often thought that these two groups worked in relative isolation from each other. In fact, the underlying assumption was that within the Persianate order the Sanskrit cosmopolis was marginalised and possibly in a state of decline. Furthermore, the Islamic and Sanskritic orders were more
13. Pollock 2001a.
14. Pannikar 1980.
15. Van der Veer 2001.
16. Pollock 2001a. 
or less separate spheres with little connection between them. Closer scrutiny reveals that the interaction between intellectuals of these two linguistic orders was far more frequent and deeper than is often thought. Medicine, astronomy, and philosophy were clearly constellations where there is ample evidence of the sociality of scholars belonging to the two orders, and the emergence of entangled and hybrid forms of knowledge is clearly evident. And finally, we have the vernacular intellectuals who wrote in more than a dozen regional languages on diverse subjects ranging from theology to hagiography, the practical arts such as medicine, and belles-lettres. And here, too, Pollock sees a striking parallel with Europe of the first half of the second millennium that witnessed a proliferation in literary production in the vernaculars. ${ }^{17}$

Consequently, rather than being seen an age of scholarly stagnation, the period from 1550 to 1750 is now considered as one of an intellectual renewal that Pollock considers "one of the most creative eras in Indian intellectual history." ${ }^{18}$ Across the disciplines we witness a renewed production of texts in vyākarana (grammar), mimāmsa (hermeneutics), nyāya (logic), dharmasāstra (traditional law), alankārasāstra (poetics or aesthetics), àyurveda (medicine), jyotisha (astral sciences), and ganita (mathematics). This renewal was witnessed along regional complexes extending over the subcontinent and further characterized by an increased production of texts in the disciplines just mentioned, obviously generated by a renewal within each of the said disciplines, which required the introduction of new conceptual categories and discursive practices. This meant that traditional problems came to be formulated in new ways and were expressed in new discursive styles and genres of scholarly writing. ${ }^{19}$

And, more recently, Jonardon Ganeri has been speaking of a lost age of reason more or less concurrent with the South Asian modernity that Pollock and others discuss. ${ }^{20}$ Just as the Dark Age is now problematised, so must the historiography of ages of decline and lost ages. Nevertheless, the transition from past forms of knowledge to the new forms of knowledge was not just about the organization or classification of knowledge but as much about the methods of producing it. The claim to novelty was justified on the grounds of greater coherence, economy, and explanatory ability. It is in this sense that Pollock and others begin to see the rise of an Indian modernity. For, as he writes: "If we accept the construction of modernity that takes it to be...

17. Ibid.

18. Ibid.

19. Pollock 2004.

20. Ganeri 2011. 
a different mode of structuring temporality, whereby the continuous present of tradition gives way to a world in which the past and the future are discrete phenomena, a modernity of a certain sort must be said to confront us in 17thcentury India." ${ }^{21}$ There existed several modalities of coping with the arrival of a new ecumene on the Indian subcontinent that reveals itself to us in the variety of conversations across equally variegated disciplinary borders.

The circulation of knowledge between the Sanskrit and Arabic constellations of knowledge dates back at least to the 8th century AD. By the 12th and 13th century, Indian scholars probably learned to read Arabic texts from Persian scholars. Two areas of the astral sciences particularly benefited from the conversations that occurred between the two ecumenes. At the level of technical instruments used in astronomy, the astrolabe probably arrived in India in the 11th century, but it was only towards the end of the 14th century, during the reign of Firuz Shah Tughlaq (r. 1351-1388), that the production of astrolabes received a fillip in the subcontinent. Firuz Shah went on to encourage the publication of manuals in Persian and Sanskrit. Hindu and Jaina jyotisis responded enthusiastically to the introduction of the device that they referred to as the yantra raja (the king of instruments) and went on to produce a large number of manuals and devices with Sanskrit inscriptions on them that S. R. Sarma calls Sanskrit astrolabes. In the last millennium, between 1370 and the middle of the 19th century, the yantra raja was easily among the most enthusiastically received foreign devices or ideas among scholarly communities of pundits. ${ }^{22}$

Furthermore, testimony to the new conversations between the two orders was the invention of an astral science referred to as täjika. ${ }^{23}$ One of the first texts on tājika astronomy was the Täjikatantrasara (also called the Karmaprakasika, the Ganakabhusana, or the Manusyajataka). The text was probably written around 1388. For the first century and a half after its appearance, tajjika was confined to that portion of the peninsula where Hindus, Muslims, and Jainas shared common commercial and intellectual interests. By the end of the 16th century, the influence of the Mughal Empire extended over the Western peninsula. ${ }^{24}$ Abdul Rahim Khan-i-Khanan (1556-1626), an important savant

21. Pollock 2001a: 22.

22. Sarma 1999.

23. The term täjika as employed here alludes to an amalgam of Indian and Persian astronomy. The term itself was employed in Sanskrit to connote immigrants from Iran in India. But as astronomical/astrological practice it came to designate the amalgam of Indian and Arab/Persian genethlialogy. See Pingree 1997: 79, 87.

24. Pingree 1997. 
and official in the Mughal court, wrote a celebrated poem on tājika called the Khetakautuka, comprising 124 verses in Persian and Sanskrit. The Moghul court gradually acquired an interest in tājika. The Jyotisraja (chief astrologer) in Akbar's (r. 1556-1605) court was Nilakantha, who composed a widely popular text called the Tajjikanilakanthi. Nilakantha was also commissioned by Todaramalla ${ }^{25}$ to work on a Sanskrit encyclopaedia, the Todarananda, that he probably completed in 1587 . The work was a compendium of all Sanskrit learning that preceded the age. However, the Tajikanilakanthi was introduced into the same region where Greek astrology had been introduced a millennium earlier. It reached all parts of India by the $17^{\text {th }}$ century. ${ }^{26}$ The excitement over the new knowledge reflected in the texts produced indicates that pragmatic considerations prevailed over the preservation of tradition. Several textual stratagems were employed to legitimate the tajikatantra or the methods of tajjika. There was a constant return to the dual origins of the subject, and a narrative of reincarnation was introduced to appropriate tājika within Sanskritic astronomy. ${ }^{27}$ These cross-cultural interactions were further reflected in the works of Siddhichandra, who was the interlocutor for Hindawi culture for the great Persian litterateur and historian in Akbar's court, Abu Fazl (1551-1602). Siddhichandra later became a teacher of Akbar's sons, for whom he recited poetry in Persian. These exchanges between the two traditions continued during the centuries of Mughal rule. In the late 17th century, the Maharastrian Hindu litterateur and renunciant Kavichandra Sarasvati, was an intimate of Dānishmand Khan, Moghul courtier and companion of François Bernier (1625-1668), who translated Descartes into Persian-whether this translation was further transmitted is still an open question..$^{28}$

The decline of the Mughal Empire had set in during the late 17th century when it encountered the limits of its economic and territorial expansion. Interestingly enough, its greatest failure, according to some, was the inability to innovate in the scientific, intellectual, and technical fields. But this view leans heavily on a remark of François Bernier, who writes that the Mughals made few attempts to reach out to the variety of developments of Western science and technology, and that their sole preoccupation was restricted in significant ways to artillery. By the early decades of the 18th century, Delhi was still the seat and capital

25. Todaramalla was a physician and was a minister or vizīr in the court of Akbar around about 1577 ce. See ibid.

26. Ibid.

27. Ibid.

28. Wujastyk 2005. 
of the Mughal Empire, whose dominion was rapidly shrinking. ${ }^{29}$ But as far as cultural life was concerned, it was a period of brilliance. The 18th century was witness to a resurgence in painting, musicology, and literature-in fact the golden age of Urdu literature more or less commences in the middle of the 18th century, as prose simultaneously begins to coruscate as a new literary genre in the several vernaculars. This naturally led Panikkar to pose the question whether empire was any longer necessary for a cultural efflorescence. The decline of the Mughal Empire was not necessarily accompanied by a decline of the domestic economy till the middle of the 18th century. This is explained by the mushrooming of new regional states where new centres of economic growth flourished. During the phase extending from 1740 to 1760 - one of growing anarchy-poets, artists, writers, and the well-to-do citizenry left Delhi in search of patronage and refuge in the provincial capitals. ${ }^{30}$ As the empire declined, musicians, poets, and litterateurs moved to kingdoms at the periphery of empire seeking new patrons and establishing new schools and traditions. Consequently, the provincial capitals, infused with new ideas and styles, became centres of renewal and innovation. ${ }^{31}$

Historians of science and technology have since contested the notion of the decline of the sciences in late-medieval and early-modern India. On the contrary, the eclipse of the knowledge systems and ecumenes of the subcontinent is now located in the politics of colonialism and the substitution of several coexisting epistemic regimes by another. ${ }^{32}$ Internal structural contradictions that triggered the decline of the Mughal Empire led to the decline and withdrawal of state patronage of scholarly activity. While the Mughal Empire declined, the astronomer-king Jai Singh's (r. 1699-1743) dominion expanded territorially during the first half of the 18th century, located as it was along crucial trade routes. It could be reasonably suggested that Jai Singh and other rulers were inspired by the cosmopolitan practices of Mughal predecessors.

As a scholar and student of mathematics and astronomy, Jai Singh was driven by a passion to build a number of astronomical observatories. He went on to design and build a new city at the base of a hill on which stood the traditional dynastic palace and fortress. The modern city of Jaipur, also the new capital of the Amber dynasty, was geometrically planned, with streets broad enough to accommodate a procession of six elephants across-clearly

29. Chandra 2008.

30. Ibid.

31. Panikkar 1980.

32. Cohn 1997. 
a symbolic display of his imperial power. ${ }^{33}$ The city was built on entirely new lines and was unlike anything that preceded it; and scholars often see in its geometrical design a reflection of Jai Singh's mathematical disposition. As a ruler and administrator, he was endowed with a far more cosmopolitan ethos, which has led historians of another generation to make of him a visionary prefiguring a conception of a composite religious and cultural Indian state. We get a flavour of this cosmopolitanism when we examine his astronomical project, which in its own times was possibly among the largest projects undertaken in that century, not just on the subcontinent but anywhere. From a purely astronomical point of view, Jai Singh's greatest contribution comes from the importance accorded to observational astronomy evident in the masonry observatories that he supported and for which he designed some instruments. In addition, he contributed towards authoring a treatise in Persian, the Zij- $i$ Muhammad Shahi, which in a qualified way was positioned within the Islamic tradition of zij astronomy, whose genealogy is traced back to the work of Ulugh Beg (1394-1449). This aspect of Jai Singh's immediate astronomical projects is noteworthy. ${ }^{34}$ In addition to which, he was also acquainted and engaged with the work of the French mathematician and astronomer Philippe de la Hire (1640-1718). While grounded in jyotisha-vidya (knowledge of astronomy and astrology in Sanskrit), his familiarity with Greco-Arabic ilm al hayá was substantial enough to prompt him to refine Ulugh Beg's tables, a task for which he would seek resources from within European astronomy as well. In short, one of the objectives of this project in astronomy was to consolidate his appreciation of the development of the astronomy of his times - whether Asian or European. ${ }^{35}$ Furthermore, as just pointed out, he designed new astronomical instruments in order to improve the accuracy of his measuring devices. This entailed the construction of five mammoth observatories across northern India. The previous two goals were subordinate to the overarching objective, which was to compile an accurate set of astronomical tables in order to correctly predict eclipses and introduce major calendar reform.

In addition to this astronomical activity, he supported an immense project in the translation of Ptolemy and Euclid into Sanskrit and Persian. He actively sought European contacts and enrolled some of them into his project. Jai Singh's first exposure to the new developments in the sciences was through the Jesuit Superior in Goa, the Portuguese Manuel de Figuereido, who visited his court in Jaipur in 1728. He succeeded in arousing Jai Singh's interest and

33. Tillotson 2006.

34. Sharma 1995.

35. Ibid. 
led a delegation of Jai Singh's scholars to Lisbon. The delegation is reported to have returned to Jaipur in 1730 with the tables of Philippe de la Hire and John Flamsteed (1646-1719). Xavier da Silva, a recognised astronomer and physician, accompanied the delegation on its return journey to Jaipur. ${ }^{36}$ As suggested earlier, in addition to the immediate astronomical imperatives that drove this collaboration, an attempt by Jai Singh to model himself on the cosmopolitan persona of Akbar cannot be ruled out.

However, with shifting patronage in certain fields, creativity reached new heights, and in some others it strove to attain new forms of expression. ${ }^{37}$ The problem that remains, without idealizing the Indian past, is whether the dynamism of intellectual and creative life was disrupted by the onset of colonialism. ${ }^{38}$ The newer work from the perspective of a social theory premised on the idea of multiple modernities suggests that by the end of the 18th century the Sanskrit cosmopolis went into rapid decline; on the other hand, the vernacular traditions of knowledge and writing were themselves being revolutionized. The dynamism of the Sanskrit ecumene declined with the consolidation of colonial power and ended the power of Sanskrit to shape Indian intellectual history; after 1820, European modernity irreversibly "changed the rules of the game of language and power." ${ }^{39}$ These were on the point of vanishing when they were supplanted by different principles of epistemology, sociality, and polity. However, it is here that we move into the domain of counterfactuals and confront a number of tropes that have come down to us from Orientalist, imperial, and nationalist historiography, which, along with a revised social theory, beg for a re-examination of the history of knowledge as well as the history of education, its forms and institutions of the pre-colonial period. ${ }^{40}$

\section{Colonial India: engrafting modern mathematical ideas}

The encounter between "modern sciences" and the knowledge forms of the subcontinent date back to the beginnings of modernity itself. Scholarship over the last decade has pointed out how modernity has been constitutive of

\footnotetext{
36. Forbes 1982.

37. Panikkar 1980.

38. Panikkar 1995.

39. Pollock 2001: 400; Bayly 1997.

40. Baber 1996.
} 
the identity of modern science ${ }^{41}$. On the other hand, both imperial history and postcolonial history of science have frequently played upon the radical break or discontinuity that marks the eclipse of the so-called traditional knowledge systems of India and the ascent of modern science that came to be institutionally anchored in the period of early to late colonialism. ${ }^{42}$ Running against these trends are the interpretive frames of "engraftment" and "entanglement." Recognizing the limitations of epistemological or osmotic explanations for the circulation of knowledge, theories of engraftment focus upon the varied uses that traditional or modern knowledge resources were put to by equally varied learned communities. This re-examination divulges the complexity of the process of engraftment and opens the black box of hybrid knowledge by moving the history of knowledge to the history of knowability that traces the genealogy of how "particular knowledges become powerful through their value in furthering specific socio-cultural projects." 43

On the other hand, the idea of entanglement operates at two levels. As historical sociology it has a bearing upon social theory by bracketing some of the central concepts that frame historical narratives within quotation marks, thereby pressing for a more complex understanding of the phenomenon and processes involved. Thus, in the sphere of religion and politics, it has been argued that "national culture in Britain and India developed in relation to a shared colonial experience" in which the notions of religion and secularity were common to imaginings of the British and Indian nations respectively, and finally that these imaginaries developed in relation to issues of gender, race, language, and science. ${ }^{44}$ In fact, the argument can be extended, as has become evident in the critiques of the idea of "science" that proliferated in the 1980s, that the sciences in the colonies played a fundamental role in reconstituting the identity of Western science. The point was further underscored in the elaboration of one version of postcolonial theory of science. ${ }^{45}$ This section reflects on what this historiography means by taking up a couple of mathematical works in English, Hindi, and Urdu published between the second half and the end of the 19th century.

The starting point requires a shift of focus from the history of science to the history of knowledge. That shift recognizes that science as a concept is

41. See the essays in Habib and Raina 2007.

42. Roughly speaking the process is inaugurated by the early 1820 s and continued into the early decades of the 20th century.

43. Dodson 2010: 15 .

44. Van der Weer 2001: 3.

45. Harding 1998; Raina 2007. 
inscribed within the institutional structure of the university and disciplines that emerged in 19th-century Europe and thereby broadens the quest of the history of science to other ways of knowing and knowledgeability. As far as the history of sciences of South Asia is concerned, these changes have been accompanied by other developments discussed in the previous section that have revised our appreciation of pre-colonial knowledge systems, the knowledge game, and learned communities, throwing up a challenge for one version of postcolonial history of the region, questioning the idea of civilization and nation as adequate units for historical study, and challenging modernization theory on which much of this history has been premised - reflecting the deeply entangled nature of the categories and histories of West and East.

Nevertheless, an important concern relates to the ways in which one might include in a narrative those constellations of knowledge that do not follow the pattern proposed by Joseph Needham, who used the metaphor of rivers flowing into the $\mathrm{sea}^{46}$-in other words that are not rendered visible in the histories of the modern scientific disciplines - namely, those that escape the net of presentism of modern science. These presentist practices extend beyond the conceptualization of science but are structured by notions of spatiality and nation. In Refashioning Iran, Tavakoli-Tarighi reminds us that between 1750 and 1850 there were more books in Persian published from the Indian cities of Delhi, Lucknow, Hyderabad, and Lahore than from Iran, parts of Turkey, and Central Asia. ${ }^{47}$ The author further argues that the Hegelian conception of history renders such texts and projects homeless: ignored in India, ignored in Iran. "The convention of history with borders has created many homeless texts that have fallen victim to the fissure of Indian and Iranian nationalism. Although abolished as the official language of India in the 1830s, the intellectual use of Persian continued and Persian publications in 19th-century India outnumbered those produced in other languages." ${ }^{48}$ Publishers from cities in the Indian subcontinent also published more Persian books than their counterparts in Iran. Furthermore, "the literary and historical texts edited and published in India achieved canonical status in the neighbouring Iran." 49

My colleague and collaborator, S. Irfan Habib, and I have worked on one 19th-century mathematician and one astronomer-savant who belonged to this order. ${ }^{50}$ The work we did on the mathematician Ramchundra (1821-1880)

\footnotetext{
46. Chemla 1999.

47. Tavakoli-Targhi 2001.

48. Ibid:: 9 .

49. Ibid.

50. Raina and Habib 2004.
} 
and the work we intend to undertake on the mathematical work of Munshi Zakaullah (1832-1910) of Delhi ${ }^{51}$, known in his time as the geometer of Delhi, we believe now needs to be reframed by another historiography. The standard historiography concerning the beginnings of the modern system of education in India is shared by imperial history, postcolonial history, and triumphalist accounts of science. This historiography sees Thomas Babington Macaulay's "Minute on Indian education" (1835), which led to the withdrawal of British financial support from Sanskrit and Arabic language book publication and education in India, as the end of the Anglicist-Orientalist controversy, the end of engraftment, or the possibility of engrafting modern scientific knowledge onto a Sanskritic base. ${ }^{52}$ The end of this phase marks the introduction of systems of learning on British lines and the marginalization of the existing systems - a total rupture with tradition.

However, the idea of engraftment was premised on the notion that study of Sanskrit "was worthy in its own right" and that the mathematics (arithmetic and algebra) of the Hindus was "grounded on the same principles as those of Europe." An educational methodology referred to as "engraftment" was adopted so as to "allure the learned natives of India to the study of European science and literature, we must... engraft this study upon their own established methods of scientific and literary instruction." Dodson suggests that it was a "conciliatory policy" proceeding from an understanding that "a rational comparison of the contents of Indian and European science would always

51. Habib 2000.

52. As the stranglehold of colonial rule became increasingly evident between 1800 and 1830 , the programme of engraftment steered by the Orientalists was challenged by colonial officials who wondered about the utility of this programme of education. Thomas Babington Macaulay (1800-1859) proposed a fund "for the purpose of promoting learning in India in any way which may be thought most advisable," directed at "the intellectual improvement of the people of this country." But this meant that hereafter instruction was to be in English for in the region "there are no books on any subject which deserve to be compared to our own, whether, when we can teach European science, we shall teach systems which, by universal confession, wherever they differ from those of Europe differ for the worse, and whether, when we can patronize sound philosophy and true history, we shall countenance, at the public expense, medical doctrines which would disgrace an English farrier, astronomy which would move laughter in girls at an English boarding school..." In other words, not only was engraftment out of vogue, but the patronage of educational systems would shift from the Madrassa and the Sanskrit College at Calcutta to institutions reconfigured on lines where "the English language might be well and thoroughly taught." See Macaulay 1835. 
favour the latter. ${ }^{53}$ We saw the failure of Ramchundra's project as an outcome of the installation of a new epistemic regime and pedagogy.

Recent studies have prompted a revision of this position following extensive research done on science textbooks in the vernacular languages of South Asia, and the new histories of knowledgeability have argued for a revision of the idea of radical rupture-the notion that the 1840s marks a pedagogic break with the past is untenable. On the contrary, the new histories suggest what might have been intuitively obvious to those doing a historical sociology, namely that the process of engraftment continued for several decades despite Macaulay's "Minute" and in fact went on to shape systems of education and a number of historical discourses in the century that followed-not just in the colonial cities of Mumbai and Calcutta but at the traditional centres of learning such as Delhi, Banaras, and Pune. At Banaras, so-called traditional Sanskrit scholars and mathematicians like the legendary Bāpu-Deva Sāstri (1821-1890), and his contemporary Vithala Rāo collaborated with James Robert Ballantyne ${ }^{54}$ in the translation of Bacon's Novum Organum into Sanskrit, responded to the work, and critiqued it. ${ }^{55}$ But the translations of these mathematician-philosophers gave credence to the idea of the nyay a constituting the methodological organon of the Indian sciences and prepared the ground for the reception of inductivism as a theory of science among India's first generation of modern scientists and historians of science..$^{56}$

In Delhi, Bāpu-Deva Sāśtri and, later, Pandit Sudhākar Dwivedī and Laksmishankar Mishrā served as go-betweens in the translation of terminology and concepts from three distinct mathematical traditions - the Sanskritic, the Arabic and modern mathematics, finally rendering these works into Hindi. ${ }^{57}$ Similarly, in Maharashtra, as Mādhav Deshpānde has so carefully chronicled for us, the scholarly activities of cultural amphibians such Pandit Rāghavchārya, Krishnashāstri Chiplunkar and his son Vishnushastri Chiplunkar, Balsāśtri Jāmbhekar, and others mediated the transition between different knowledge constellations and theories of knowledge. More specifically, as teachers and producers of mathematics and science textbooks, they played a central role in the 19th century translation of texts into Sanskrit and the vernaculars. ${ }^{58}$

\footnotetext{
53. Dodson 2010: 75.

54. Ballantyne was the Superintendent of Benares College between 1846 and 1861 .

55. Dodson 2010.

56. Raina 2011.

57. Raina 2013.

58. Deshpānde 2001.
} 
The science textbooks produced for instruction became sites for translating the unfamiliar into the language of familiarity. This in itself was a very innovative task that needs to be explored through novel spectacles rather than as has been traditionally done by studies in the popularization of science that work either with a deficit theory or, as Shapin once put it, osmotic models. ${ }^{59}$ Furthermore, the textbooks themselves became the medium for the production of reverse commentaries and the contestation of colonial constructions of the universe of knowledge in the subcontinent. In the process, through strategies of domestication and naturalization, the pursuit of modern science was legitimated. ${ }^{60}$ In the early decades of the nineteenth century, inspired in part by the studies of German and British Indologists, new historical imagined communities were created, wherein second-order constructions of the so called Indian sciences were produced. By the early decades of the 20th century, several Indian interlocutors preferred to drop the term Western to qualify modern science, their own readings having been shaped by the idea of science as a cultural universal. Several of them within their epistemological orders would have found it difficult to qualify knowledge in civilizational or ethnic terms. ${ }^{61}$

This of course poses a moral problem for historians whose theories of knowledge may be out of phase with the tradition being interpreted. The time is then ripe for new historical engagements. Postcolonial scholarship, as has been pointed out, has often functioned as an imperial sociology of knowledge and ignored the social history of knowledge on the eve of colonialism, which in a way reinforces the perspective that colonialism certainly marked the end of the Sanskrit episteme and thereby changed the rules for the generation of knowledge on the subcontinent. ${ }^{62}$ On the contrary, on this side of the knowledge divide this would require that we study the knowledge game withoutrephrasing the title of a friend's book - playing the nation game ${ }^{63}$ and do so in a more transcultural way.

One last remark that cannot escape attention of South Asia historians and this raises a question Catherine Jami has often posed to this author and several others: What about the circulation and transmission of knowledge between South Asia and East Asia? This has been and continues to be a woefully neglected and under-researched theme. Most research that has been

\footnotetext{
59. Shapin 1983.

60. Raina 2012.

61. Raina 2003.

62. Pollock 2003.

63. Zachariah 2011.
} 
done focuses upon the pre-Christian era, through the centuries of Buddhist pilgrim literature to the end of the first millennium of the Christian era. A relatively recent volume authored by Tan Chung and Geng Yinzeng seeks to survey "twenty centuries" of exchange between and across the two regions. ${ }^{64}$ The focus is not so much on "scientific ideas" as on temple cultures, imperial structures, personalities, and pilgrimage literature, drawing upon a huge corpus of writing of itinerant Buddhist monks. There is also a fairly substantial listing of historical events extending over a hundred pages. But what is bothersome is how little, if any, work at all has been done on the second millennium on the circulation of knowledge between these regions. It is likely that the volume was commissioned out of an urgently perceived omission that needs to be addressed and perhaps listings such as these will serve as a platform for the research of future scholars.

\section{BIBLIOGRAPHY}

BABER Zaheer (1996). The Science of Empire: Scientific Knowledge, Civilization, and Colonial Rule in India. Albany, State University of New York Press.

Basalla George (ed.) (1968). The Rise of Modern Science: Internal or External Factors. Lexington (Mass.), D. C. Heath.

BAYLY C. A. (1997). Empire and Information: Intelligence Gathering and Social Communication in India. 1780-1870. Cambridge/New York, Cambridge University Press.

BRETELLE-ESTABLET Florence (ed.) (2010). Looking at it from Asia: The Processes that Shaped the Sources of the History of Science. Boston Studies in the Philosophy of Science, vol. 265. Dordrecht/New York, Springer.

Chandra Satish (2008). State, Pluralism, and the Indian Historical Tradition. New Delhi, Oxford University Press.

ChemLa Karine (1999). "The Rivers and the Sea: Analysing Needham's Metaphor for the World History of Science.” In S. Irfan Habib and Dhruv Raina (eds.), Situating the History of Sciences: Dialogues with Joseph Needham. New Delhi/New York, Oxford University Press: 220-244.

CoHn Bernard S. (1997). Colonialism and its Forms of Knowledge: The British in India. Oxford, Oxford University Press.

DeshPĀNDE Madhav (2001). "Pandit and Professor: Transformations in Nineteenth Century Maharashtra." In Axel, Michaels (ed.), The Pandit: Traditional Scholarship in India. New Delhi, Manohar: 119-153.

64. Tan and Geng 2005. 
Dodson Michael S. (2010). Orientalism, Empire and National Culture: India 17701780. Delhi, Cambridge University Press.

Forbes Eric G. (1982). "The European Astronomical Tradition: Its Transmission into India, and its Reception by Sawai Jai Singh II." Indian Journal of History of Science, 17 (2): 234-243.

Fuller Steve (1997). Science. Buckingham (UK), Open University Press.

GANERI Jonardon (2011). The Lost Age of Reason: Philosophy in Early Modern India 1450-1770. Oxford/New York, Oxford University Press.

GIZYCKI Rainald von (1973). "Centre and Periphery in the International Scientific Community." Minerva, XI (4): 474-94.

GüNERgun Feza and RaInA Dhruv (eds.) (2011). Science between Europe and Asia: Historical Studies on the Transmission, Adoption and Adaptation of Knowledge. Boston Studies in the Philosophy of Science. Dordrecht/New York, Springer.

HABIB S. Irfan (2000). "Munshi Zakaullah and the Vernacularisation of Science in Nineteenth Century India." In Sehgal, Narender K., Sangwan, Satpal and Mahanti, Subodh (eds.), Uncharted Terrains: Essays on Science Popularization in Pre-Independence India, Vigyan Prasar: 54-64.

Habib S. Irfan and RaIna Dhruv (eds.) (2007). Social History of Science in Colonial India. Themes in Indian History. New Delhi, Oxford University Press.

Harding Sandra (1998). Is Science Multicultural? Postcolonialisms, Feminisms, and Epistemologies. Bloomington (Ind.), Indiana University Press.

INKSTER Ian (1988). "Prometheus Bound: Technology and Industrialization in Japan, China and India prior to 1914-A Political Economy Approach." Annals of Science, vol. 45, no. 4: 399-426.

Macaulay Thomas Babington (1835). "Minute by the Hon'ble, T. H. Macaulay, dated the 2nd February 1835." See Sharp, Henry (ed.), Bureau of Education. Selections from Educational Records, Part I (1781-1839). Calcutta, 1920. Reprint. Delhi: National Archives of India, 1965: 107-117. The text of the "Minute" is available online at http://www.columbia.edu/itc/mealac/pritchett/00generallinks/macaulay/ txt_minute_education_1835.html.

Matthiesen Ulf (2005). "Knowledgescapes: Pleading for a Knowledge Turn in Socio-Spatial Research," working paper. Erkner, Leibniz-Institute for Regional Development and Structural Planning. http://www.irs-net.de/download/ KnowledgeScapes.pdf.

Needham Joseph et al. (1954-). Science and Civilisation in China, 23 vols. published. Cambridge, Cambridge University Press.

PanikKar K. N. (1980). "Cultural Trends in Pre-colonial India: An Overview.” Studies in History, vol. II, no. 2: 62-80.

PanikKar K. N. (1995). Culture, Ideology, Hegemony: Intellectuals and Social Consciousness in Colonial India. New Delhi, Tulika Books.

Pingree David (1997). From Astral Omens to Astrology from Babylon to Bikaner. Rome, Istituto Italiano per l'Africa e l'Oriente.

Pollock Sheldon (2001), "The Death of Sanskrit," Comparative Study of Society and History, vol. 43, no. 2: 392-426. 
Pollock Sheldon (2001a). "New Intellectual Communities in 17th Century India." The Indian Economic and Social History Review, vol. 38, no. 1: 3-31.

Pollock Sheldon (2003). "Cosmopolitan and Vernacular in History." Public Culture, vol. 12 , no. 3: 591-625.

Pollock Sheldon (2004). "Forms of Knowledge in Early Modern South Asia." Comparative Studies of South Asia, Africa and the Middle East, vol. 24, no. 2: 19-21.

RaINA Dhruv (2003). Images and Contexts: The Historiography of Science and Modernity in India. New Delhi, Oxford University Press.

RAINA Dhruv (2007). "Multicultural and Postcolonial Theories of Science and Society." In Dasgupta, Jyoti Bhusan (ed.), Science, Technology, Imperialism and War. Project of History of Indian Science, Philosophy, and Culture. History of Science, Philosophy, and Culture in Indian Civilization, vol. XV, part 1. New Delhi, Centre for Studies in Civilizations: 175-194.

RaInA Dhruv (2011). "Exact and Positive: Conceptions of the Past of the Sciences in India." Lecture series: Global Concepts? Keywords and Their Histories in Asia and Europe. Heidelberg, Heidelberg University, 13 January 2011.

RaINA Dhruv (2012). “The Naturalization of Modern Science in South Asia: A Historical Overview of the Processes of Domestication and Globalization." In Renn, Jürgen (ed.), The Globalization of Knowledge in History. Max Planck Research Library for the History and Development of Knowledge Studies 1: 345-366. Edition Open Access: http://www.edition-open-access.de/studies/1/.

RaINA Dhruv (2014). "Mathematics Education in Modern India (1800-1950).” In Karp, Alexander and Schubring, Gert (eds.), Handbook on the History of Mathematics Education. Dordrecht/New York, Springer: 376-384.

Raina Dhruv and HabiB S. Irfan (2004). Domesticating Modern Science: A Social History of Science and Culture in Colonial India. New Delhi, Tulika Books.

SARma Sreeramula Rajeswara (1999). "The Astrolabe in Sanskrit." Indian Journal of History of Science, vol. 34, no. 2: 145-158.

Schaffer Simon, Roberts Lissa, Raj Kapil and Delbourgo James (eds.) (2009). The Brokered World: Go-betweens and Global Intelligence, (1770-1820). Uppsala Studies in History of Science, 35. Sagamore Beach (Mass.), Watson Publishing International.

SHAPIN Steven (1983). “Nibbling at the Teats of Science': Edinburgh and the Diffusion of Science in the 1830s.” In Inkster, Ian and Morrel, Jack (eds.), Metropolis and Province: Science in British Culture: 1780-1850. Philadelphia, University of Pennsylvania Press: 151-178.

Sharma V. N. (1995). Sawai Jai Singh and his Astronomy. Delhi, Motilal Banarsidas.

Storey William K. (ed.) (1996). Scientific Aspects of European Expansion. An Expanding World: The European Impact on World History 1450-1800, vol. 6. Aldershot (Hampshire, Great Britain), Brookfield (Vt.), Variorum.

Subrahmanyam Sanjay (2007). "Connected Histories: Notes Towards a Reconfiguration of Early Modern South Asia.” Modern Asian Studies, vol. 31, no. 3: 735-762. 


\section{Dhruv Raina}

TAN Chung and Geng Yinzeng (2005). India and China: Twenty Centuries of Civilizational Interactions and Vibrations. Project of History of Indian Science, Philosophy, and Culture: Consciousness, Science, Society, Value, and Yoga, vol. III, part 6. Delhi, Motilal Banarsidas.

TAVAKoli-TARGHi Mohamad (2001). Refashioning Iran: Orientalism, Occidentalism and Historiography. New York, Palgrave.

Tillotson Giles. 2006. Jaipur Nama: Tales from the Pink City. Delhi, Penguin Books.

VAN DER Veer Peter (2001). Imperial Encounters: Religion and Modernity in India and Britain. Princeton, Princeton University Press.

Veblen Thorstein (1919). "The Intellectual Pre-Eminence of Jews in Modern Europe." Political Science Quarterly, vol. 34, no. 1: 33-42.

Wujastyk Dominik (2005). "Change and Creativity in Early Modern Indian Medical Thought." Journal of Indian Philosophy, vol. 33, no. 1: 95-118.

ZaChariah Benjamin (2011). Playing the Nation Game: The Ambiguities of Nationalism in India. New Delhi, Yoda Press. 